\title{
交流電場により誘起される粒子分散型機能性流体の流動特性*
}

\author{
小原弘 道*1, 赤上陽一 ${ }^{* 2}$, 井畑良 亮*3 \\ 監物潤*4, 松平晏明*5
}

\section{Flow Characteristics of Particle Dispersion Type Functional Fluid Induced with AC Electric Field}

\author{
Hiromichi OBARA*6 ${ }^{* 6}$ Yoichi AKAGAMI, Ryousuke IBATA, \\ Jun KENMOTSU and Yasuaki MATSUDAIRA \\ ${ }^{* 6}$ Department Mechanical Engineering, Tokyo Metropolitan University, \\ 1-1 Minamiosawa, Hachioji-shi, Tokyo, 192-0397 Japan
}

\begin{abstract}
The flow characteristics of functional fluid, which suspended micro scale diamond particles in insulated silicon oil, were investigated by microscopic observation and micro particle image velocimetry. This functional fluid has two specific flow structures induced under the high voltage alternating electric field. One pattern of the flow structure consists of a reciprocating parallel flow generated along an electric flux line in one direction between the electrodes under low-electric intensity and high-frequency conditions. The other pattern of the flow structure consists of a rotational flow formed under high-electric-intensity and low-frequency conditions. These specific flow structures will contribute actively to a polishing process and to the development of micro fluidic devices in the future. In this study, the electric field conditions to generate the rotational flow structure were discussed. And also the detail structure of the rotational flow was investigated with velocity vector distributions and vorticity distributions.
\end{abstract}

Key Words : Functional Fluid, Magnetohydrodynamics, Polishing, Micro Fluidics, PIV

\section{1. 緒 論}

工業製品の超小型化·高性能化が求められる中, マイ クロからナ領域における微細加工技術一の高い要求 がある. その中で, 近年広く注目されている機能性流体(1) の一つである粒子分散型機能性流体を援用した新しい 研磨技術が提案 (2) (3)されている.この機能性流体を積極 的に用いた新しい研磨技術は, 絶縁溶媒中に砥粒とな るダイヤモンド粒子などを分散させた流体に交流電場を 印加することで砥粒に加工圧を与える箇所に集め, 積極 的な研磨特性を得る技術である. それらの報告の中で， 特定の電場強度・電場周波数の条件下において, 研磨 特性が向上することが報告され, 分散粒子のクラスタ形 成状態ならびに分散粒子の運動が大きく研磨特性に影 響を与えている(2)ことが明らかにされた. また, 研磨特性 が向上する条件下において, 電極間に積極的な回動を

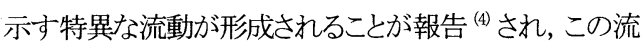

* 原稿受付 2008 年 3 月 18 日.

*1 正員, 首都大学東京大学院理工学研究科(恶 192-0397 八王 子市南大沢 1-1).

*2 正員, 秋田産業技術総合研究センター(画 010-1623 秋田市 新屋町字砂奴寄 4-11).

*3 首都大学東京大学院修士課程 [現：本田技研工業(株)]

$* 4$ 東京都立科学技術大学大学院修士課程 [現：日本ミシュラ ン(株)]

*5 首都大学東京大学院理工学研究科 [現: 名誉教授]

E-mail : obara@tmu.ac.jp
動が研磨特性向上に大きく寄与しているものと考えられ ている. しかしながら, 機能性流体に交流電場を印加す ることにより発現する特異な流動に関して, 流動形成条 件や流動特性について十分に明らかにされておらず, 高度な研磨技術確立のためには, 流動形成条件の評価 ならびに流動特性の解明が必要不可欠である.

一方, 微小な領域において積極的に流動を形成し, マイクロ流体デバイスー活用することは, 次世代医療の ためのバイオ・ナノ研究, たとえば PCR 副産物の搬送に 用いるバイオチップ等への応用が期待される. 誘起され る流動を活用したデバイスに関する様々な研究が進めら れている中で, EHD (Electrohydrodynamics) 効果として 説明される電場印加によって粒子分散型機能性流体に 誘起される流動を積極的に制御・利用する手法に関して 注目を集めており, アクチュエータの駆動 ${ }^{(5)}$ (6) や混合・ 分離()などの新しいマイクロ流体デバイスの開発が可能 になると期待されている. しかしながら, 電場に応答する 粒子分散型機能性流体に関して, これらの応用的な研 究や ER (Electro Rheological) 流体特有のレオロジ一特 性に着目した研究 ${ }^{(8)(10)}$ は広くおこなわれているものの, 交流電場下において形成される粒子分散型機能性流体 
に発現する特異な流動特性に着目した研究はおこなお れていない.

以上の背景から本報では, 交流高電場を印加した粒 子分散型機能性流体の特異な流動現象に関して, 電場 強度・電場周波数の電場条件変化による様相変化から粒 子クラスタ形成特性ならびに流動様相特性評価をおこな い, 微小な領域の速度場計測が可能なマイクロ PIV 計測 による速度場情報から流動形成特性評価をおこなうこと で, 交流電場印加された粒子分散型機能性流体の流動 特性を明らかにする.

\section{2. 実験装置および実験方法}

図 1 は流路電極部，高電圧供給システム，計測シス テムから構成される実験装置を示す，流路は，透明な ガラスプレート上に二枚の銅板(縦 $10 \mathrm{~mm}$, 横 $20 \mathrm{~mm}$, 高さ $2 \mathrm{~mm}$ ）を平行に対向配置させることで形成され

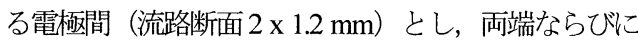
上部は開放されている．高電圧供給システムは，波形 生成装置（IWATSU FG-330）ならびに高電圧アンプ (TREK Model 609E-6)により構成されており，合わせ てPIV 計測との同期のために位相の異なる出力を生成 するために別の波形生成装置（IWATSU SQ-4015）を 用いた，波形生成装置で生成された波形は高電圧アン プで 1000 倍に増幅され，マイクロ流路を形成する両 電極に供給される.また，任意の印加電場位相におけ る流動様相を計測するために主波形生成器と同期し た波形生成器から時間遅れに相当する任意の位相を 有するトリガ信号を PIV 計測装置へ供給した. 計測シ ステムは，光学系として正立顕微鏡（OLYMPUS BH-UMA，対物レンズ 5 倍，リレーレンズ 1.5 倍）と CCD カメラ (画像観測用 Watec WAT-250, HITACHI FP-120D, IDT MotionproX3，マイクロ PIV 用 DANTEC

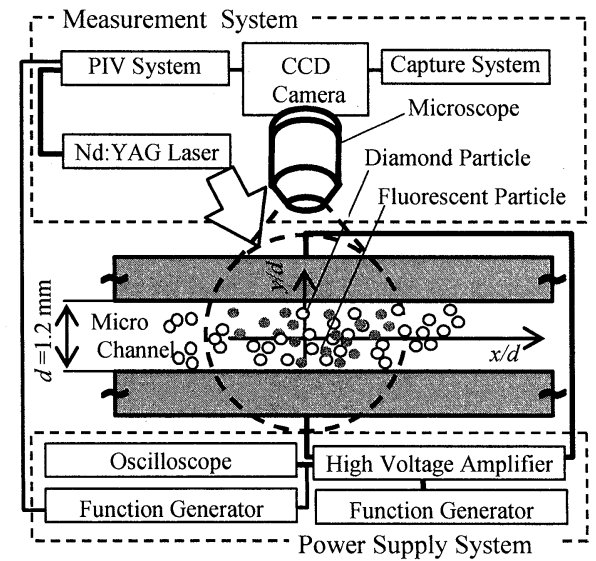

Fig. 1 Experimental Apparatus
Hi-sense Camera）ならびに光源から構成される. 光源 として画像観察用にハロゲンランプ光源ならびにマ イクロ PIV 計測用にレーザ光源（ダブルパルス Nd:YAG Laser 波長 $532 \mathrm{~nm}$ ）を用いた. マイクロ PIV 計測時には，レーザ光を透過型光源として測定部に供 給し，計測用粒子励起波長に対応した光学フィルタを 用い画像情報を取得した. また, 速度場情報は微小時 間間隔で取得された 2 枚の粒子画像より相互相関法 により PIV 計測演算処理装置（Dantec Flow Map）を用 い取得した.

供試流体は，電気絶縁性を有するシリコンオイル (信越化学工業製 $\mathrm{KF}-96$, 液温 $25^{\circ} \mathrm{C}$ 動粘度 $\nu=100$ $\mathrm{mm}^{2} / \mathrm{s}$ ）を溶媒とし, 粒径 2〜4 $\mu \mathrm{m}$ の人工ダイヤモ ンド（トーメイダイヤ製，IRM2-4）を十分に分散させ た粒子分散型機能性流体を用いた，溶媒に対する分散 粒子の濃度は 0.2～5wt.\%とし，主に 1\%に関して議論 した. なお, PIV 計測時にはポリスチレン蛍光粒子 (粒 子径 2-3 $\mu \mathrm{m}$, 䖺光波長 612nm）もあわせて混入して いるが，本実験条件の範囲においては蛍光粒子混入に よる流動特性の影響が無いことを事前に確認してい る. 実験条件は，溶媒中のダイヤモンド粒子の流動が 良好に示される矩形波（図 2）を印加波形とし，動画 観察においては電場強度 $E=0.4 \sim 2.5 \mathrm{kV} / \mathrm{mm}$, マイクロ PIV 計測においては電場強度 $E=2.5 \mathrm{kV} / \mathrm{mm}$ とした. 電場周波数は，主に粒子が活発に流動する低周波数領 域において, 動画観察では $f=0.1 〜 2.0 \mathrm{~Hz}$ について, マイクロ PIV 計測では $f=0.5 \mathrm{~Hz}$ についておこなった. 時系列変化は印加電場の極性が変化する立ち上がり 時間を基淮として位相 $\theta$ によて示し, $f=0.5 \mathrm{~Hz}$ の場 合, $\theta=180^{\circ}$ が $t=1 \mathrm{~s}$ となる. 測定領域は、流路中央を 原点とし, 電極と平行に $x$ 軸, 電極間電場方向を $y$ 軸, 高さ方向を $z$ 軸とし, $x-y$ 平面 $(z=0.9 \mathrm{~mm})$ とした.

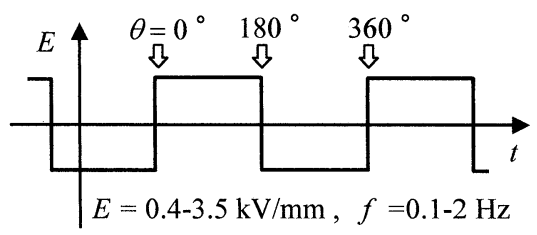

Fig. 2 Waveform of Applied Electric Field

\section{3. 実験結果及び考察}

3.1 粒子クラスタ形成特性 図 3 は供試流体 に交流電場を印加することで形成される(1) $E=1.0$ $\mathrm{kV} / \mathrm{mm}$, (2) $E=2.5 \mathrm{kV} / \mathrm{mm}$ における粒子クラスタ形成 様相を示す. 代表として, 電場周波数 $f=0.5 \mathrm{~Hz}$ にお 
ける結果を示し, 粒子濃度はクラスタ様相が確認しや すい $c=1 \%$ よりも若干低く調整したものを用いている.

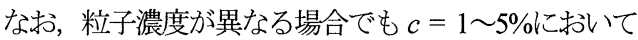
は，分布密度に差異はあるものの同様の粒子クラスタ 形成様相を示すことを確認している．絶縁溶媒に誘電 体である粒子が分散している場合, 直流電場を印加す ることで，誘電分極により電気力線に沿って粒子が連 なり鎖状のクラスタを形成する. 本実験で用いたシリ コンオイルにダイヤモンド粒子を分散させた供試流 体においても，直流電場印加時に特徽的な電場方向に 配向する長い鎖状のクラスタが形成される. 交流電場 印加時においては, 図3に示すように電場強度により 異なる粒子クラスタ様相を示す，低電場強度である (1) $E=1.0 \mathrm{kV} / \mathrm{mm}$ においては, 直流電場印加時に形成 されるクラスタの長さに比較して長さは短いものの, 直流電場印加時と同様にダイヤモンド粒子は鎖状の クラスタを形成する。一方，高電場強度である (2) $E$ $=2.5 \mathrm{kV} / \mathrm{mm}$ においては, 低電場強度の場合に示された 規模の大きい鎖状のクラスタとはならず，数粒子程度 が連なる短、鎖状，ないしは複数個のダイヤモンド粒 子が凝集した塊状のクラスタを形成寸る。これらの様 相の差異は電場周波数の差異によっても同様に確認 されており，粒子クラスタ形成特性は電場強度・電場 周波数に依存して変化する.

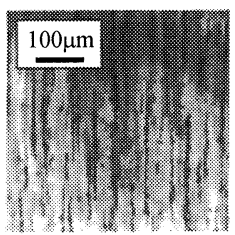

(1) $E=1.0 \mathrm{kV} / \mathrm{mm}$

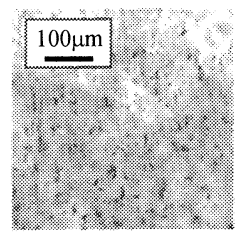

(2) $E=2.5 \mathrm{kV} / \mathrm{mm}$
Fig.3 Clustering Pattern of Particles $(f=0.5 \mathrm{~Hz})$

図 4 は粒子濃度 $c=1 \%$ における電場強度・電場周波 数変化による粒子クラスタ形成特性を動画観察なら びに静止画画像情報から整理した図である. $E=0.5$ $\mathrm{kV} / \mathrm{mm}, f=2.0 \mathrm{~Hz}$ では, クラスタの形成は他の条件に 比し小規模であり,ここではクラスタ無しとして整理してい る.この条件をのぞく, 低い電場強度，高い電場周波数 においては，前述した鎖状に粒子が連なる鎖状のクラ スタが形成される. 電場強度の増加, 電場周波数の低 下にともない鎖状のクラスタは短くなり塊状のクラ スタが多く観察されるようになる。ここでは大きく二 種類のクラスタ形成状態として整理しているが，二種 類の境界となる電場条件においては，遷移的なクラス 夕形成特性となる。 これらの粒子クラスタ形成特性は,
誘電分極特性などの直接的な電場条件の影響ではな く，後述する流動特性に大きく影響を受けていると考 えられ，流動形成によるせん断や粒子群の衝突などの 影響を受けてクラスタの様相が変化すると考えられ る.

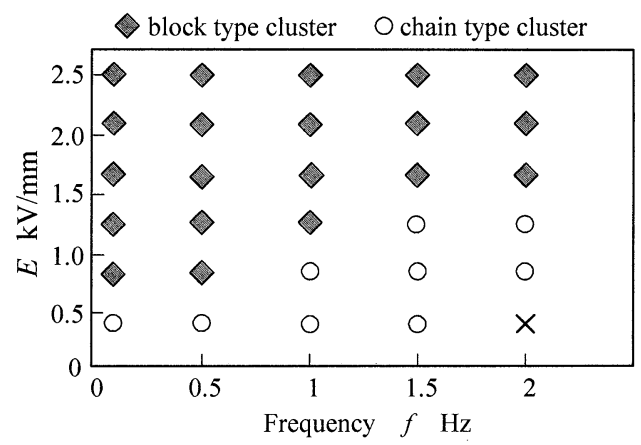

Fig.4 Classification of Particles Clustering Patterns $(c=1 \%)$

$3 \cdot 2$ 流動様相特性 図 5 は代表的な流動様相と して粒子濃度 $c=1 \%$, 電場周波数 $f=0.5 \mathrm{~Hz}$ の電場印加 時に形成される電場強度 $E=1.0,2.5 \mathrm{kV} / \mathrm{mm}$ における マイクロ PIV 計測による速度ベクトル分布を示す。こ こでは流動が明瞭に形成される印加電場の立ち上がり 後, $t=0.17 \mathrm{~s}$ (位相 $\theta=30^{\circ}$ )における分布を示寸. なお, 電場強度の差異により誘起される速度が異なることから， (1) $E=1.0 \mathrm{kV} / \mathrm{mm}$ に関してはベクトル長を 20 倍にして 示しており, 基準ベタトル長さを図上に示す. 絶縁性の 溶媒であるシリコンオイルに誘電体であるダイヤモンドを 分散させた供試流体は, 交流電場印加によって大きく分 類して二種類の流動を形成する. 低電場強度(1) $E=1.0$ $\mathrm{kV} / \mathrm{mm}$ においては, 電極間のいずれの位置においても 電気力線方向である $y$ 軸に平行に負から正一と向かう
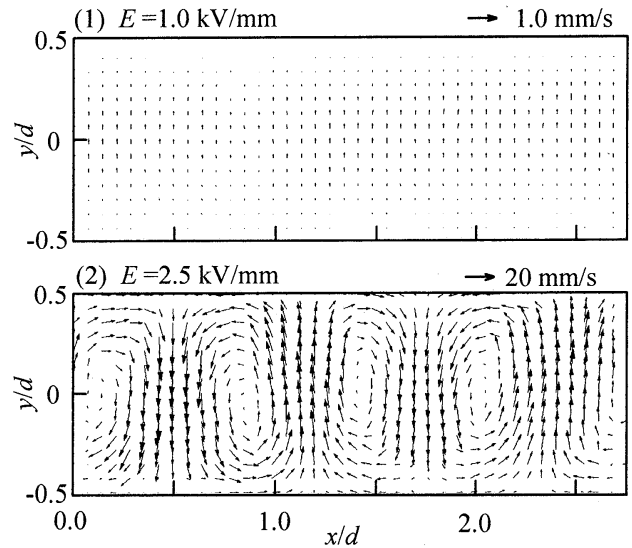

Fig. 5 Typical Flow patterns of Particle Dispersion Type Functional Fluid $(f=0.5 \mathrm{~Hz}, c=1 \%)$ 
同一方向の速度ベクトル分布を示寸. この速度ベクト ル分布から，ダイヤモンド粒子並びに溶媒は，電極間 において同一面内で電気力線に平行に往復する流動

（以下，平行流動）を形成する.この流動は，印加電 場の立ち上がりに同期して流動を形成し，印加電場の 極性変化に対応して流動方向の反転を示寸，一方，高 電場強度 (2) $E=2.5 \mathrm{kV} / \mathrm{mm}$ においては, 電極間に一定 間隔に向きの異なる速度を有するべクトル分布を示 し, 誘起される速度は低電場強度において誘起される 速度に比し 20 倍以上増大寸る. 一定間融に形成され る向きの異なる速度によって，それらに挟まれる領域 に同一面内において回転する流動（以下，往復回転流 動）を形成する.この往復回転流動の回転方向は印加 電場の極性変化に同期して変化する。 この往復回転流 動は既報(2)の研磨特性向上が見られた印加電場条件に おいて形成される回動と同様の流動と考えられ，この 往復回転流動が形成される条件を整理することで，さ らなる高度の研磨特性を得ることが可能になると考 えられる。

図 6 は粒子濃度 $c=0.2 \%$ (i ) 〜 5\%（iv）における 電場強度・電場周波数の変化による粒子の流動様相特 性を，前述の流動様相に着目して整理した図である. 流動様相を(A)〜(D)に分類し，それぞれを模式図とし て図上部に凡例とともに示寸. 流動様相は, 電場印加 による微小振動のみが観察され電極間での流動が形 成されない流動なし (A), 図 5(1) に示した電場周波数 に対応し電極間での流動が形成され同一断面内では 同一方向一の流動を示寸平行流動 (B), 電場の印加初 期に平行流動が形成され時間経過とともに電場の極 性変化に同期した同一面内の往復回転流動一と変化 する遷移流動 (C), および図 5(2)に示した電場の印加 直後から電極間に安定して一定の間隔で往復回転流 動が形成される往復回転流動 (D)に分類している.な お，各図中に $c=1 \%$ における往復回転流動を形成する 境界となる条件に関して，時間経過後に往復回転流動 が形成される遷移流動も含む往復回転流動・遷移流動 と往復回転流動が形成されない平行流動の境界を点 線で示し，平行流動形成の境界となる条件として平行 流動と流動なしの境界を一点鎖線で示す、いずれの粒 子濃度においても, 電埸強度の増加にともない, (A) 流 動なし, (B) 平行流動, (C) 遷移流動, (D) 往復回転流 動と流動特性は変化する，また，電場周波数変化に対 して, 電場周波数の減少にともない, 電場強度の増加 時における変化之同様に(A) 流動なし, (B) 平行流動, (C) 遷移流動, (D) 往復回転流動と流動特性は変化を 示す。これらを整理すると，往復回転流動は高電場強
度，低電場周波数条件において形成される．また，こ の電場強度・電場周波数の変化による流動特性の変化 と，前述の高電場強度，低電場周波数になることで塊 状のクラスタが示される粒子クラスタ形成特性は対 応しており，粒子クラスタ形成特性は流動特性に大き く影響を受けていると考えられる. 粒子濃度の影響は, $\mathrm{c}=1 \sim 5 \%$ においては, 高い電場周波数域において往復 回転流動形成条件に若干の差異があるものの，遷移流 動を含めた往復回転流動を形成する条件（点線）は粒 子濃度によらず同一である．さらに，平行流動形成条
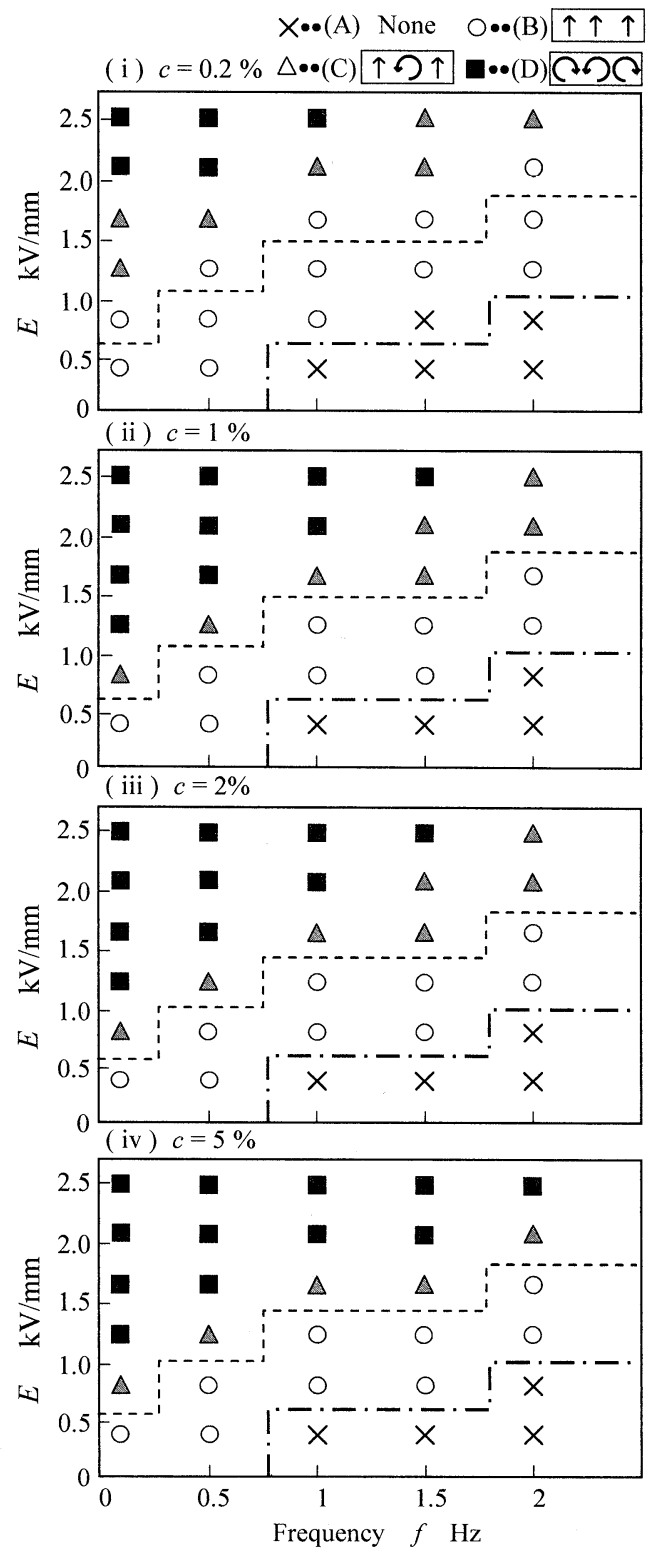

Fig.6 Classification of Particles Motion 
件（一点鎖線）に関しても，粒子濃度によらず同一で ある. 電場強度・電場周波数のいずれに関しても同条 件で往復回転流動・平行流動が形成されることから, $\mathrm{c}=1 \sim 5 \%$ の濃度範囲における流動特性は粒子濃度に 影響を受けない. ただし，粒子濃度が非常に少ない条 件である $c=0.2 \%$ においては, 平行流動を形成する条 件に関して $E=1.0 \mathrm{kV} / \mathrm{mm}, f=1.5 \mathrm{~Hz}$ を除いては他の粒 子濃度条件の特性と同一であるものの, 安定した往復 回転流動が形成される条件が，他の高い粒子濃度条件 における特性と比較して, 高い電場強度条件, 低い電 場周波数条件へ之变化している. また， $c=0.2 \%$ 以外 の粒子濃度条件においては往復回転流動が形成され た条件において，遷移流動となっている. 粒子濃度が 極度に低い条件に関して流動形成の電場条件が若干 異なることから，往復回転流動形成には最低限度の粒
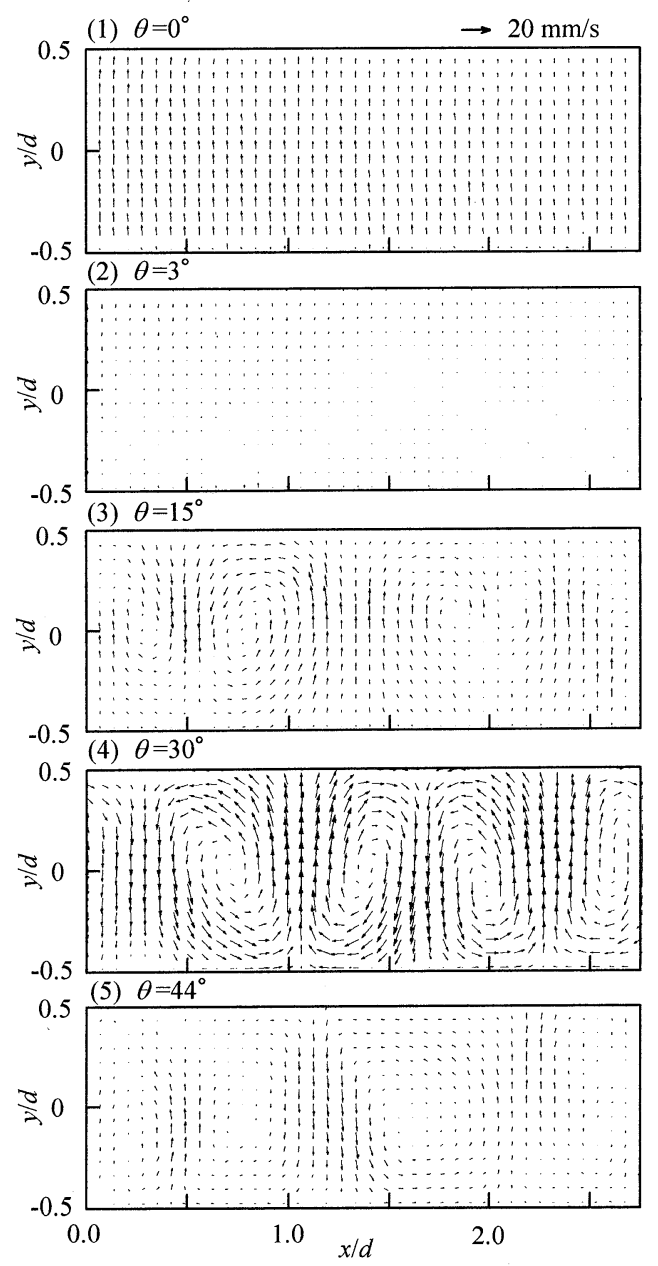

Fig. 7 Generating Process of Rotational Flow $(E=2.5 \mathrm{kV} / \mathrm{mm}, f=0.5 \mathrm{~Hz}$ )
子濃度が必要となると考えられ, 今後, 流動形成機構 解明のためには, 流動形成に必要な最低限度の粒子濃 度の評価が必要であると考えられる。これらのことか ら，極度に粒子濃度が少ない場合をのぞいて，粒子濃 度数\%の条件範囲においては, 交流電場印加により形 成される流動特性は粒子濃度に依存せず，電場強度・ 電場周波数の電場条件に支配される.これらのことか ら以降では $c=1 \%$ の結果に着目して議論する.

$3 \cdot 3$ 往復回転流動形成特性図 7 は往復回転 流動形成条件である電場強度 $E=2.5 \mathrm{kV} / \mathrm{mm}$, 電場周波 数 $f=0.5 \mathrm{~Hz}$ における各位相時刻における流動様相を 速度ベクトル分布で示す.なお, ここでは印加電場の 極性が変化する立ち上がり後に着目し, $\theta=0^{\circ}$ から $\theta=44^{\circ}$ までの速度ベクトル分布を示す, ただし, 計 測環境の制約からそれぞれの位相において独立に計 測したものである. 電場印加に対して各位相時刻に形 成される流動様相は再現性が高く, 連続的な情報とし て評価可能であることを確認している. 電場印加直後 $\theta=0^{\circ}$ (1)において, 計測全領域に正の方向を有する一 様なベクトルが示されている.これは, 別途おこなっ た高速度カメラによる動画観察から電場印加の立ち 上がり時の急激な電場変化により粒子が微動する現 象をとらえたものであり, 後述寸る速度分布からもこ の動きは流動形成には至らず往復回転流動形成には 直接的に影響を及ぼさない. $\theta=3^{\circ}$ (2)において, 前述 の粒子の微動は継続せず, 全領域においてほとんど速 度ベクトルは示されない. $\theta=15^{\circ}$ (3)において, その 速度にばらつきはあるものの局所的に電気力線方向 である $y$ 軸方向の正・負のベクトルが一定間隔に示さ れている. $\theta=30^{\circ}$ (4)においては, 一定の間隔で正方 向, 負の方向の速度は大きくなり, これらの間に往復 回転流動が形成されている. $\theta=44^{\circ}$ (5)において, 往 復回転流動を形成していた流動の速度は減衰し, 往復 回転流動は示されるものの $\theta=33^{\circ}$ に比較して小さく なっている. 図示は割愛しているが, $\theta=44^{\circ}$ 以降の位 相において速度は急激に減衰し, 交流印加電場の極性 が入れ替わる $\theta=180^{\circ}$ 以降まで流動は形成されず, 交 流印加電場の極性の入れ替わり後は, 同様の流動変化 が繰り返される.これらのことから, 電極間に一定の 間隔て形成される往復回転流動は, 印加電場の立ち上 がり（立ち下がり）後に，応答するまでの時間の遅れ を有して各電極方向に向かう一定の間隔で局所的に 誘起される正・負の向きの異なる電気力線方向の流動 によって形成されると考えられる.

図 8 は, 印加電場の極性が変化する立ち上がり後に 着目した位相 $\theta=15^{\circ}, 22^{\circ}, 30^{\circ}$ における渦度分布 
を示す. なお, $\theta=15^{\circ}, 30^{\circ}$ に関しては, 前述の速度 ベクトル分布に対応した渦度分布となっている.ここ では反時計回りを正とし，正の渦度を実線，負の渦度 を点線で示している. (1) $\theta=15^{\circ}$ においては, 前述の ベクトル分布で示された $y$ 軸方向の速度を有する一定 間隔で局所的に誘起される流動をはさんで左右とな る位置に往復回転流動に対応する正負の渦度分布が 示されており, 回転する流動が形成され始めている. (2) $\theta=22^{\circ}$ においては，規則正しく一定間隔に正負交 互に渦度分布が示されており最も往復回転流動が発 達した位相となっている. (3) $\theta=30^{\circ}$ においては, 速 度ベクトル分布においても明膫に示されていたよう に往復回転流動に対応した渦度分布が示されている ものの，渦度分布の集中度合いは $\theta=22^{\circ}$ に比べ若干 の拡散を示し, 渦度の強さは減衰をはじめている. 以 降の位相においては, 速度べクトル分布に示した特性 と同様に，急激に渦度は減衰する．図示は割愛してい るが, 印加電場の極性が入れ替わる $\theta=180^{\circ}$ まで渦度 分布は示されない. すなわち, 電場印加により誘起さ れる往復回転流動は，電場極性の変化に伴い応答時間 に対応した位相の遅れを有して形成され, $\theta=22^{\circ}$ 付近 において最大に発達した後に, すみやかに減衰する。
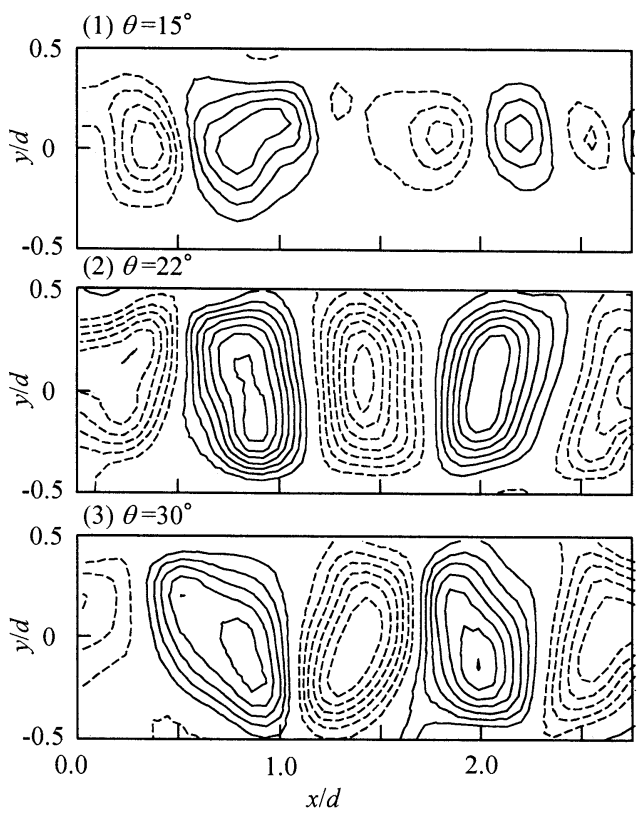

Fig. 8 Vorticity Distributions $(E=2.5 \mathrm{kV} / \mathrm{mm}, f=0.5 \mathrm{~Hz})$

図 9 に各位相時における最大速度, 最大渦度を示す。 各位相の速度場情報を代表する情報として，それぞれ の位相における電極間 $y$ 軸方向速度の最大值，ならび に洞度の最大值を抽出し，それらを平均化したもので
ある. 最大速度に着目すると速度べクトル分布の時間 変化に示されたように，印加電場の極性が変化する立 ち上がり直後である $\theta=0^{\circ}$ においては, 流動は形成さ れず，印加後に電場極性変化から数 $\mathrm{ms}$ の応答時間の 後に加速的に速度は堌加を示寸. その後, 電場印加後, $\theta=20^{\circ} \sim 30^{\circ} \quad(t=0.11 \mathrm{~s} \sim 0.17 \mathrm{~s})$ で極大值を有する. 極大值を示した後に, 流動は急速に減衰を示し, 電場 極性が切り替わる $\theta=180^{\circ}$ まで供試流体に電場は印 加されているものの，流動は形成されない，渦度に関 しては, ばらつきはあるものの速度変化と同様に $\theta$ $=20^{\circ} \sim 30^{\circ} \quad(t=0.11 \mathrm{~s} \sim 0.17 \mathrm{~s})$ に極大值を有し, 極 大值を示した後は, 急激に減衰し, 印加電場の極性が 変化する $\theta=180^{\circ}$ まで渦度は示されない. 往復回転流 動の形成特性は，前述の速度分布・渦度分布特性と合 わせて, 印加電場の極性が変化する立ち上がり（立ち 下がり）後に，若干の応答時間を有して急速に形成さ れ，その後急速に減衰する.

これらのことから，流動の詳細形成機構に関しては 今後の検討が必要であるが, 往復回転流動は, 印加電 場極性変化に対応し，応答時間を有して一定の間隔で 局所的に誘起される電気力線方向の正・負の向きの異 なる加速的な流動が発達することによって形成され る.

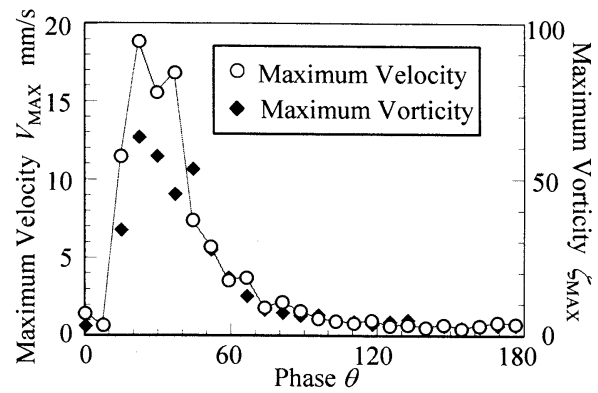

Fig.9 Maximum Velocity and Vorticity $(E=2.5 \mathrm{kV} / \mathrm{mm}, f=0.5 \mathrm{~Hz})$

\section{4. 結 論}

本報では，交流高電場を印加した粒子分散型機能 性流体の特異な流動現象に関して, 電場強度・電場周 波数の電場条件変化による様相変化から粒子クラス 夕形成特性ならびに流動样相特性評価をおこない， マ イクロ PIV 計測による速度場情報加流動形成特性評 価をおこない，交流電場印加された粒子分散型機能性 流体の流動特性を明らかにした，以下に，おもな結 果を示す。 
（1）交流電場印加された粒子分散型機能性流 体は電場強度・電場周波数の変化によって, 電極 間において同一面内で電気力線に平行に往復する平 行流動，ならびに，同一面内において一定間融に回転 する往復回転流動を形成する.

（2）交流電場印加により形成される流動様相 特性は, 電場強度の増加と電場周波数の減少にともな い, 流動なし, 平行流動，遷移流動，往復回転流動と 変化する. 粒子濃度数\%の条件範井において電場印加 により形成される流動の特性は粒子濃度に依存せず, 同条件で平行流動，往復回転流動が形成される.

（3）粒子クラスタ形成特性は, 低電埸強度・高電 場周波数においては鎖状のクラスタを形成し，電場強 度の増加，電場周波数の低下にともない塊状のクラス 夕を形成し，これらの特性は流動特性に大きく影響を 受ける.

（4）往復回転流動は, 印加電場極性変化に対応し, 応答時間を有して一定の間隔で局所的に誘起される 電気力線方向の正・負の向きの異なる加速的な流動が 発達することによって形成される.

\section{謝辞}

本研究実施にあたり, 名古屋大学 梅原徳次教授 には多大なご助言をいただき，ここに感謝の意を 表します。また，本研究は，日本学術振興会加ら の科学研究費補助金（No.16760135）ならびに日本 科学財団笹川科学研究助成による支援によりおこ なわれたものでここに感謝の意を表します。

\section{文献}

(1) Nakano M., State of Art and Future Prospects on Functional Fluids, Journal of the Japan Society for
Precision Engineering, Vol. 72, No.7 (2006), pp. 813-816.

(2) Akagami Y., Asari K., Fujita T.,Jeyadevan B., Umehara N., Development of Fine Finishing Process using Diamond Particle Dispersion Type Functional Fluid, Transactions of the Japan Society of Mechanical Engineers. Series C, Vol. 66, No. 649(2000), pp. 3168-3173.

(3) Akagami Y., Umehara N., Development of electrically controlled polishing with dispersion type ER fluid under AC electric field, Wear, Vol. 260(2006), pp.345-350.

(4) Tamura H., Obara H., Akagami Y., Matsudaira Y. Microscopic Flow Characteristics of Particle Dispersion type functional fluid impressed AC voltage, Proceedings of the Fluids engineering conference, No.03-81(2003-11), pp.128.

(5) Takemura K., Yokota S., Edamura K., Micro Artificial Muscle Actuator using Jet Flow of Electro-conjugate Fluid, Transactions of the Japan Society of Mechanical Engineers. Series C, Vol. 71, No. 708(2005), pp. 2571-2577.

(6) Takemura K, Kozuki H., Edamura K., Yokota S. A micromotor using electro-conjugate-fluid improvement of motor performance by using saw-toothed electrode series, Sensors and Actuators A: Physical, Vol. 140, No.1(2007), pp. 131-137.

(7) Obara H., Ikeda T., Tashiro S., Micro Vortex Formation with Alternating Electric Field, Proceedings of the 16th National Meeting of the Society for Chemistry and Micro-Nano Systems, No.01(2007-11), pp.72

(8) Hao T., Electrorheological suspensions, Advances in Colloid and Interface Science, Vol. 97(2002), pp. $1-35$

(9) Nakano M., Rheological properties and flow behavior of electro-/magneto-rheological fluids, Journal of the Visualization Society of Japan, Vol.27, No.105 (2007), pp. 103-110.

(10) Tsukiji T., Utashiro T., Flow of ER Fluids between Two Parallel-Plate Electrodes for Sinusoidal Electric Fields, Transactions of the Japan Society of Mechanical Engineers. Series B, Vol. 63, No. 608(1997), pp. 1221-1228. 